\title{
Analisis Kebutuhan Pengembangan Lembar Kerja Siswa Berbasis Penemuan Terbimbing Kelas VIII Sekolah Menengah Pertama
}

\author{
Aan Putra, Hendra Syarifuddin
}

(C) 2019 JEMS (Jurnal Edukasi Matematika dan Sains)

This is an open access article under the CC-BY-SA license (https://creativecommons.org/licenses/bysa/4.0/) ISSN 2337-9049 (print), ISSN 2502-4671 (online)

\begin{abstract}
Abstrak:
Pemahaman konsep matematika merupakan salah satu kemampuan dasar yang harus dikuasai oleh siswa sebagai modal awal untuk menguasai kemampuan matematis yang lebih kompleks. Untuk mengoptimalkan pemahaman konsep matematis siswa, proses pembelajaran matematika yang memfasilitasi siswa untuk menemukan konsep dan mengkonstruksi sendiri pemahamannya tentang konsep tersebut merupakan salah satu solusi. Penelitian ini bertujuan untuk menganalisis kebutuhan siswa terhadap pengembangan bahan ajar berupa lembar kerja yang dapat memfasilitasi siswa menemukan dan mengkonstruksi konsep matematika. Data dikumpulkan melalui wawancara, lembar observasi, angket dan analisis dokumen. Hasil pengumpulan data menunjukkan bahwa (1) pemahaman konsep siswa tergolong rendah, (2) proses pembelajaran belum memfasilitasi siswa menemukan dan mengkonstruksi konsep, dan (3) bahan ajar yang digunakan hanya berupa ringkasan materi dan sekumpulan soal. Berdasarkan hasil analisis kebutuhan, peneliti merekomendasikan pengembangan bahan ajar berbasis penemuan terbimbing dalam bentuk lembar kerja siswa untuk mempermudah guru dalam membimbing siswa dalam melakukan kegiatan penemuan.
\end{abstract}

Kata Kunci : Analisis Kebutuhan; Lembar Kerja Siswa; Pembelajaran Penemuan Terbimbing; Kelas VIII

\begin{abstract}
:
The mathematical concepts understanding was one of the basic abilities that must be mastered by students as an initial capital to master more complex mathematical abilities or skills. To optimize students' mathematical concepts understanding, the process of learning mathematics that facilitates students to find concepts and construct their own understanding of these concepts was an solution. This study aims to analyze student needs for developing teaching materials in students' worksheets form that can facilitate students to discover and construct mathematical concepts. The data collected through interviews, observation sheets, questionnaires and document analysis. The results of data collection show that (1) students' mathematical concepts understanding was low, (2) the learning process has not facilitated students to find and construct their concepts, and (3) teaching materials used were just as summary of material and some sets of questions. Based on the results of the needs analysis, the researcher recommends the development of teaching materials based on guided discovery like students' worksheets to facilitate the teacher in guiding students in conducting the discovery activities.
\end{abstract}

Keywords : Need Analysis; Students' Worksheets; Guided Discovery Learning; Eighth-Grade Students

\section{Pendahuluan}

Salah satu tujuan pendidikan nasional adalah mengembangkan potensi siswa menjadi insan yang berakhlak, cakap, kreatif, berilmu dan mandiri (Kemendikbud, 2003). Tujuan pendidikan nasional tersebut terurai dalam bentuk yang lebih spesifik dan dituangkan dalam beberapa mata pelajaran yang wajib pada berbagai jenjang pendidikan, salah satunya adalah mata pelajaran matematika. Materi matematika yang diberikan di sekolah disesuaikan dengan kebutuhan siswa dalam menyelesaikan permasalahan sehari-hari. Ini berarti mempelajari mate-

Aan Putra, Institut Agama Islam Negeri Kerinci

Aanputra283@gmail.com

Hendra Syarifuddin, Universitas Negeri Padang

hendrasy@yahoo.com 
matika tidak terbatas pada siswa yang hanya berminat mengambil profesi di bidang matematika seperti guru matematika, matematikawan, ahli statistik, insinyur, pakar teknologi informasi dan lainnya. Lebih dari itu, semua siswa dituntut menguasai konsep-konsep dasar matematika untuk melatih pola pikir dan cakap dalam memahami dunia sekitar yang tidak terlepas dari konsep matematika.

Kecakapan matematika (mathematics literacy) setiap individu sangat diperlukan untuk memahami berbagai fenomena serta sebagai bekal keberhasilan dalam bertahan hidup saat ini dan masa mendatang. Dengan kata lain, pada tingkat tertentu kecakapan matematika menjadi salah satu faktor penentu kelangsungan hidup individu dan kemajuan suatu peradaban. Dua visi utama pembelajaran matematika adalah mengoptimalkan pemahaman konsep matematika sebagai bekal menyelesaikan masalah dan ilmu pengetahuan lainnya serta melatih kemampuan siswa dalam memecahkan mmasalah, berpikir sistematik, kritis, cermat, bersifat objektif dan terbuka untuk menghadapi masa depan yang penuh ketidakpastian (Sumarmo, 2010).

Kemampuan paling mendasar sebagai pijakan dalam menguasai kemampuan yang lebih tinggi maupun kecakapan matematis adalah kemampuan pemahaman konsep. Pemahaman konsep matematika memberikan pengertian bahwa materi-materi yang diajarkan kepada siswa bukan hanya sekedar hapalan. Dengan pemahaman konsep matematika siswa diharapkan dapat lebih mengerti akan konsep atau materi pelajaran itu sendiri, keterkaitan antar konsep, dan menggunakan konsep dalam menyelesaikan masalah. Pemahaman konsep merupakan salah satu tujuan pembe-lajaran matematika yang mutlak harus dicapai sebab pemahaman akan suatu konsep sangat mendukung untuk memahami konsep berikutnya, atau dengan kata lain pemahaman suatu konsep menjadi prasyarat untuk memahami konsep berikutnya (Kesumawati, 2008).

Namun laporan studi internasional memperlihatkan kenyataan yang sebenarnya dari kualitas pendidikan kita terutama pada jenjang pendidikan SMP. Laporan hasil survey PISA (Programme International for Student Assesment) 2015 memberikan gambaran adanya masalah dalam sistem pendidikan di Indonesia khususnya pada pembelajaran matematika yang menyebabkan para siswa Indonesia belum bisa bersaing dengan siswa dari negara lain. Kemampuan matematika siswa Indonesia berada pada tingkatan kognitif mengetahui (knowing) yang merupakan tingkatan terendah menurut kriteria tingkatan kognitif. Siswa Indonesia belum dapat memahami dan menerapkan pengetahuan dasar yang dimiliki untuk menyelesaikan masalah (applying), serta belum mampu memahami dan menerapkan pengetahuan dalam masalah yang kompleks, membuat kesimpulan, serta menyusun generalisasi (reasoning) (OECD, 2016).

Menyikapi masalah rendahnya kemampuan matematis siswa, penggunaan pembelajaran penemuan terbimbing dapat dijadikan sebagai salah satu alternatif solusi yang dapat dicobakan. Model penemuan terbimbing (discovery learning) merupakan pilihan yang tepat untuk meningkatkan pemahaman konsep dan kemampuan penalaran matematis. Keuntungan pembelajaran dengan penemuan terbimbing antara lain siswa aktif dalam berpikir dan bernalar untuk menemukan hasil akhir. Selain itu siswa lebih memahami konsep karena siswa mengalami sendiri proses penemuan konsep. Sesuatu yang diperoleh dengan cara ini akan lebih bermakna dan lebih lama diingat (Suherman, 2003). Pendapat tersebut secara tersirat menyebutkan bahwa pembelajaran penemuan terbimbing mampu meningkatkan pemahaman konsep dan melatih kemampuan penalaran matematis siswa. Pendapat ini dipertegas oleh hasil penelitian yang membuktikan bahwa pembelajaran matematika dengan penemuan terbimbing 
dapat meningkatkan pemahaman konsep dan kemampuan penalaran matematis siswa sekolah menengah pertama (Bani, 2011).

Dalam penerapannya, pembelajaran dengan penemuan terbimbing membutuhkan perangkat pembelajaran yang didasarkan pada karakteristik dan langkah-langkah penemuan terbimbing sebagai pendukung terlaksananya pembelajaran penemuan terbimbing. Sumber belajar tersebut dapat berupa buku sumber, modul maupun lembar kerja siswa. Peneliti memilih pengembangan lembar kerja pada penelitian ini karena melalui lembar kerja siswa sangat memungkinkan untuk mengarahkan siswa menemukan sendiri konsep-konsep matematika. Berbeda dengan buku sumber atau modul yang lebih banyak menyajikan konsepkonsep dalam bentuk jadi. Hal ini didasarkan pada pendapat yang menyatakan bahwa salah satu tujuan penggunaan bahan ajar termasuk lembar kerja siswa adalah untuk membantu siswa dalam menemukan konsep. Bahan ajar harus dilengkapi dengan pertanyaan-pertanyaan analisis yang membantu siswa dalam mengaitkan fenomena yang mereka amati dengan konsep yang akan mereka bangun dalam pikiran mereka (Praswoto, 2010).

Pengembangan bahan ajar berupa lembar kerja siswa berbasis penemuan terbimbing telah pernah dilakukan pada beberapa penelitian baik pada mata pelajaran Matematika maupun mata pelajaran Fisika, Biologi, Kimia dan lainnya (Pramudi, Yennita \& Primairyani, 2016; Selviana, 2016). Pengembangan lembar kerja siswa pada materi Matematikapun beragam (Yuliyanto \& Jailani, 2014; Adawiah, 2016; Surbakti, 2016; Indriani, Niswah \& Arifin, 2017; Yanti \& Arcat, 2017). Pengembangan tersebut disesuaikan dengan kebutuhan siswa terutama mempertimbangkan kemampuan matematis yang akan difasilitasi.

Sebelum memutuskan pengembangan bahan ajar, permasalahan yang terjadi di lapangan masih memerlukan penelitian dan analisis yang lebih mendalam untuk mengungkap permasalahan yang terdapat dalam pembelajaran matematika serta penyebabnya, pelaksanaan pembelajaran serta kendala yang terjadi serta penggunaan bahan ajar dan kekurangannya. Rangkaian analisis ini diharapkan dapat memberi gambaran pelaksanaan pembelajaran dan permasalahannya sehingga dapat dirumuskan alternatif solusi dan rekomendasi pengembangan bahan ajar yang membantu proses pembelajaran jika dibutuhkan (Yusnia \& Suparman, 2018). Oleh karena itu, penelitian ini bertujuan untuk melakukan analisis kebutuhan siswa terhadap lembar kerja berbasis penemuan terbimbing sebagai upaya meningkatkan pemahaman konsep matematis siswa.

\section{Metode}

Jenis penelitian ini adalah penelitian kualitiatif deskriptif yang bertujuan untuk menganalisis kebutuhan siswa terhadap bahan ajar yang dapat memfasilitasi siswa untuk menemukan dan mengkonstruksi konsep matematika. Analisis kebutuhan ini mencakup analisis pemahaman konsep matematis siswa, analisis pelaksanaan pembelajaran, analisis persepsi siswa, analisis kurikulum, analisis konsep dan analisis bahan ajar. Subjek pada penelitian ini adalah siswa kelas VIII SMP Negeri 1 Kerinci, selain itu juga melibatkan dua orang guru Matematika pada SMP tersebut sebagai informan penelitian. yang diambil berdasarkan purposive sampling. Data penelitian dikumpulkan melalui tes pemahaman konsep matematis, lembar observasi pelaksanaan pembelajaran, wawancara guru, angket persepsi siswa, lembar analisis dokumen kurikulum dan lembar analisis bahan ajar. Metode pengumpulan data, instrumen yang digunakan dan tujuan tiap tahap analisis kebutuhan disajikan pada Tabel 1. 
Tabel 1. Kegiatan Pengumpulan Data pada Analisis Kebutuhan

\begin{tabular}{lll}
\hline $\begin{array}{c}\text { Metode } \\
\text { Pengumpulan } \\
\text { Data }\end{array}$ & $\begin{array}{c}\text { Instrumen } \\
\text { Pengumpulan Data }\end{array}$ & \multicolumn{1}{c}{ Tujuan } \\
\hline Tes & $\begin{array}{l}\text { Tes pemahaman } \\
\text { konsep matematis }\end{array}$ & $\begin{array}{l}\text { Mengidentifikasi tingkat capaian pembelajaran khususnya } \\
\text { pemahaman konsep matematis siswa. }\end{array}$ \\
\hline Wawancara & Pedoman wawancara & $\begin{array}{l}\text { Mengungkap kendala yang ditemui oleh guru; model, } \\
\text { metode dan sumber belajar pembelajaran yang digunakan; } \\
\text { dan tanggapan guru tentang pengembangan bahan ajar } \\
\text { berbasis penemuan terbimbing. }\end{array}$ \\
\hline Observasi & Lembar observasi & $\begin{array}{l}\text { Mengamati keterlaksanaan peran guru sebagai fasilitator } \\
\text { yang membelajarkan siswa dan kendala yang dihadapi. }\end{array}$ \\
\hline Angket & Angket & $\begin{array}{l}\text { Mengungkapkan karakteristik siswa, persepsi siswa } \\
\text { terhadap matematika dan spesifikasi sumber belajar yang } \\
\text { dinginkan. }\end{array}$ \\
\hline $\begin{array}{l}\text { Analisis } \\
\text { kurikulum }\end{array}$ & $\begin{array}{l}\text { Lembar } \\
\text { dokumen }\end{array}$ & $\begin{array}{l}\text { Menganalisis kesesuaian tujuan pembelajaran matematika } \\
\text { dan perangkat pembelajaran yang digunakan oleh guru. }\end{array}$ \\
\hline Analisis konsep & $\begin{array}{l}\text { Lembar analisis } \\
\text { dokumen }\end{array}$ & $\begin{array}{l}\text { Menganalisis kesesuaian, keluasan, kedalaman, kecukupan } \\
\text { dan urutan konsep serta kaitan antar konsep }\end{array}$ \\
\hline $\begin{array}{l}\text { Analisis bahan } \\
\text { ajar }\end{array}$ & $\begin{array}{l}\text { Lembar analisis } \\
\text { dokumen }\end{array}$ & $\begin{array}{l}\text { Menilai kelebihan dan kekurangan bahan ajar yang sudah } \\
\text { ada }\end{array}$ \\
\hline
\end{tabular}

Hasil analisis kebutuhan digunakan sebagai dasar merumuskan rekomendasi pengembangan bahan ajar berbasis penemuan terbimbing. Rekomendasi tersebut paling sedikit mencakup aspek materi, aspek isi, aspek tampilan dan aspek bahasa.

\section{Hasil dan Pembahasan}

Analisis kebutuhan bertujuan untuk mengumpulkan informasi mengenai permasalahan yang terdapat dalam pembelajaran matematika serta penyebabnya, pelaksanaan pembelajaran serta kendala yang terjadi, penggunaan bahan ajar dan kekurangannya, mengidentifikasi kesesuaian, keluasan, kedalaman, kecukupan dan urutan konsep serta kaitan antar konsep berdasarkan kurikulum, serta merumuskan kembali indikator dan cakupan materi yang dibutuhkan untuk mencapai indikator pembelajaran (Yudhi, 2017). Hasil analisis kebutuhan dijadikan sebagai dasar menentukan alternatif solusi dan rekomendasi spesifikasi bahan ajar yang harus dikembangkan.

\section{Hasil Tes Pemahaman Konsep}

Peneliti mengungkap pemahaman konsep matematis siswa pada salah satu materi yang sudah dipelajari oleh siswa yaitu sistem persamaan linear dua variabel (SPLDV). Peneliti memberikan 3 soal pemahaman konsep kepada 22 orang siswa kelas VIII. Soal tes yang diberikan dapat dilihat pada Gambar 1. 
1. Jelaskan pengertian persamaan linear dua variabel (PLDV) dan sistem persamaan linear dua variabel (SPLDV).

2. Berikan masing-masing satu contoh dan satu bukan contoh dari PLSV dan SPLDV.

3. Dua buah bilangan asli memiliki jumlah 19. Selilih dua bilangan tersebut adalah 5. Berapakah bilangan yang lebih kecil?

\section{Gambar 1. Soal Tes Pemahaman Konsep Matematis Siswa}

Dari hasil tes terlihat bahwa masih sedikit persentase siswa yang memperoleh skor ideal. Hal ini menunjukkan bahwa pemahaman konsep matematis siswa yang diwakili oleh tiga indikator tersebut masih belum optimal. Persentase perolehan skor siswa untuk tiap soal disajikan pada Tabel 2.

Tabel 2. Hasil Tes Pemahaman Konsep Matematis Siswa

\begin{tabular}{|c|c|c|c|c|c|c|c|}
\hline \multirow{2}{*}{ Kemampuan } & \multirow{2}{*}{ Indikator } & \multirow{2}{*}{$\begin{array}{l}\text { No. } \\
\text { Soal }\end{array}$} & \multicolumn{5}{|c|}{ Persentase Perolehan Skor } \\
\hline & & & 0 & 1 & 2 & 3 & 4 \\
\hline \multirow{3}{*}{$\begin{array}{l}\text { Pemahaman } \\
\text { konsep }\end{array}$} & $\begin{array}{l}\text { Menyatakan ulang } \\
\text { konsep }\end{array}$ & 1 & $9,09 \%$ & $31,82 \%$ & $36,36 \%$ & $22,73 \%$ & - \\
\hline & $\begin{array}{l}\text { Memberi contoh dan } \\
\text { bukan contoh }\end{array}$ & 2 & $0,00 \%$ & $36,36 \%$ & $36,36 \%$ & $27,27 \%$ & - \\
\hline & $\begin{array}{l}\text { Menggunakan konsep } \\
\text { dalam perhitungan } \\
\text { sederhana }\end{array}$ & 3 & $4,55 \%$ & $27,27 \%$ & $31,82 \%$ & $22,73 \%$ & $13,64 \%$ \\
\hline
\end{tabular}

Jawaban siswa terhadap tiga indikator pemahaman konsep yang diuji mengindikasikan bahwa pemahaman konsep matematika siswa masih jauh dari yang diharapkan. Sementara itu, tantangan yang dihadapi oleh siswa jauh lebih besar yaitu kemampuan berpikir tingkat tinggi yang diujikan pada ujian nasional. Hasil ujian nasional siswa SMP pada mata pelajaran matematika beberapa tahun terakhir masih belum bisa dibanggakan (Herawaty, 2017).

\section{Hasil Wawancara Guru}

Dari wawancara yang dilakukan dengan dua guru Matematika SMP Negeri 1 Kerinci, diperoleh beberapa informasi. Pertama, beberapa kendala yang ditemui olah guru dalam pembelajaran adalah kemampuan siswa yang bervariasi sehingga dibutuhkan bahan ajar yang cocok untuk semua siswa. Kedua, keterbatasan bahan ajar baik dalam segi kuantitas maupun kualitas. Ketiga, guru lebih cenderung menggunakan cara belajar konvensional karena dinilai lebih efektif dalam penggunaan waktu dan siswa lebih cepat mengerti materi yang diajarkan karena langsung pada poin-poin penting saja. Keempat, bahan ajar yang digunakan selama ini memiliki beberapa kekurangan misalnya hanya berupa ringkasan materi dan kumpulan soal.

Pemilihan cara belajar konvensional seperti ceramah dan tanya jawab yang dilakukan oleh guru dengan pandangan bahwa cara tersebut lebih hemat waktu merupakan langkah yang keliru. Selain itu, klaim guru bahwa siswa lebih cepat mengerti adalah pengakuan yang tidak sesuai dengan hasil tes pemahaman konsep siswa yang peneliti lakukan. Permasalahan yang 
sebenarnya adalah keterbatasan kemampuan guru dalam mengelola kelas dan keterbatasan bahan ajar yang digunakan (Taqiyyah, Subali \& Handayani, 2017).

\section{Hasil Analisis Pelaksanaan Pembelajaran}

Berdasarkan angket penilaian siswa terhadap pelaksanaan pembelajaran oleh guru diperoleh informasi beberapa kekurangan guru dalam pembelajaran antara lain guru jarang mengingatkan materi yang telah dipelajari, guru terlalu aktif melebihi kapasitasnya sebagai fasilitator yang membelajarkan siswa, guru belum memberi ruang yang cukup bagi peserta didik untuk menarik kesimpulan secara lebih mandiri, dan guru sangat jarang mengingatkan materi yang akan dipelajari pada pertemuan berikutnya. Persentase penilaian siswa terhadap sebagian aktifitas guru dapat dilihat pada Gambar 2.

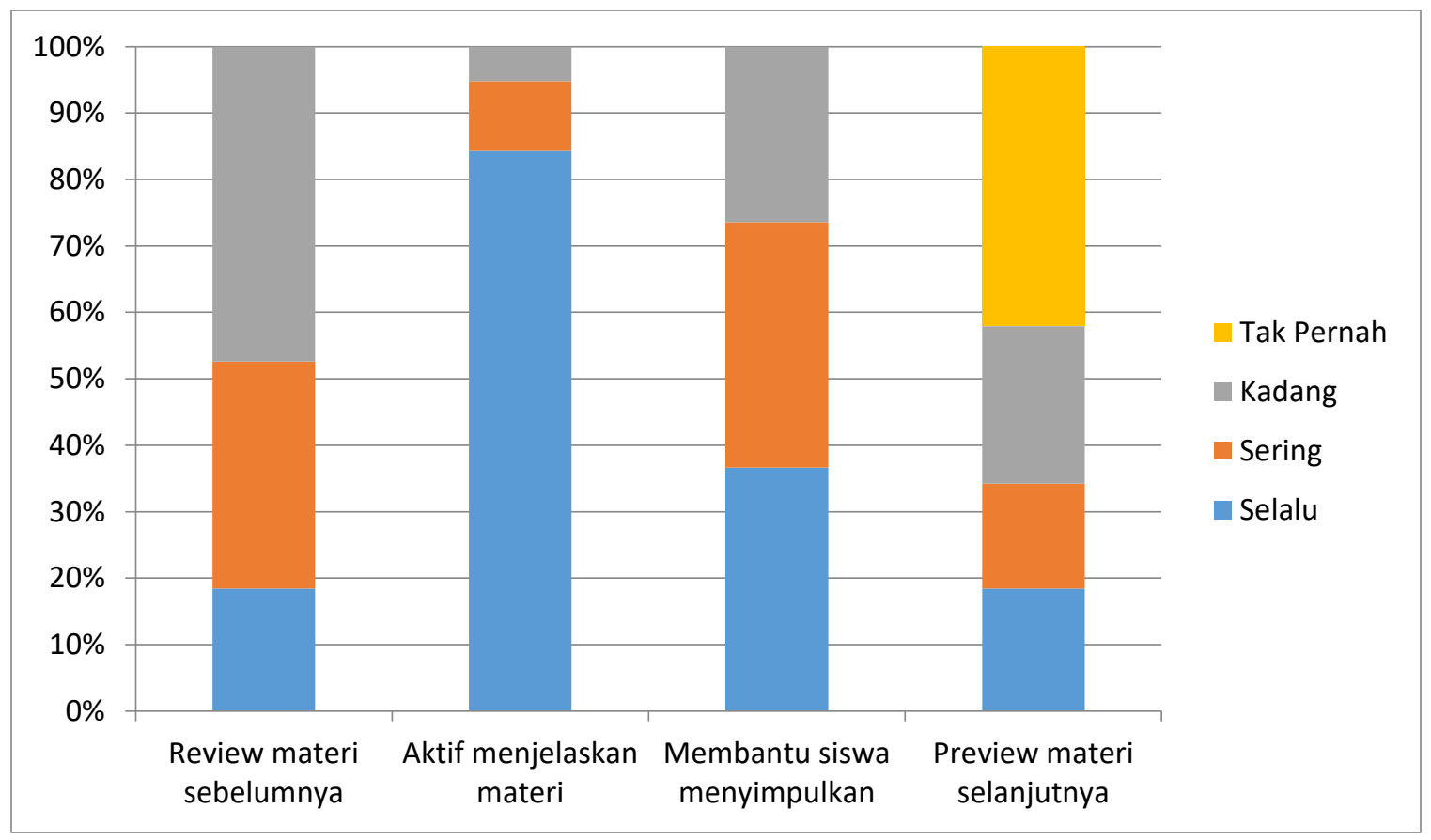

\section{Gambar 2. Penilaian Siswa terhadap Cara Mengajar Guru}

Hasil observasi peneliti terhadap dua guru matematika menunjukkan bahwa salah satu guru telah mereview materi prasayarat dan mengaitkan materi sebelumnya dengan materi yang akan dipelajari. Selain itu, kedua guru yang diobservasi belum memfasilitasi siswa mengkonstruksi sendiri konsep-konsep matematika melalui kegiatan penemuan serta belum memberi ruang yang cukup untuk siswa menyimpulkan sendiri materi yang telah dipelajari. Ini berarti kegiatan pembelajaran yang dilakukan oleh guru sudah mengacu pada usaha membelajarkan siswa namun peran guru masih sangat dominan sehingga siswa belum mendapat ruang yang cukup untuk mengkonstruksi pengetahuannya sendiri melalui kegiatan penemuan.

\section{Hasil Analisis Angket}

Untuk mendapatkan informasi tentang spesifikasi produk yang diinginkan oleh siswa, peneliti memberikan angket kepada 38 orang siswa kelas VIII. Hasil analisis angket 
mengungkapkan bahwa 65\% siswa menganggap matematika sulit dan sangat sulit dipahami, $89 \%$ siswa cukup suka matematika, $73 \%$ siswa menyadari pentingnya matematika dan $82 \%$ siswa menilai bahan ajar yang digunakan tidak menarik. Ketidakmenarikan bahan ajar berupa buku paket yang digunakan memiliki penyebab yang beragam, 22\% siswa beralasan tampilan bahan ajar tidak menarik, 14\% beralasan bahan ajar tidak membantu memahami materi, 66\% beralasan bahan ajar terlalu banyak memuat soal.

\section{Hasil Analisis Kurikulum}

Pada analisis kurikulum telah dilakukan telaah terhadap kurikulum khususnya pada materi lingkaran kelas VIII berupa analisis terhadap rumusan indikator pencapaian kompetensi materi lingkaran yang tertera pada silabus. Berdasarkan penilaian peneliti, perlu dilakukan perubahan susunan rumusan indikator pada materi lingkaran. Perubahan susunan rumusan indikator dalam materi seperti terlihat pada Tabel 3.

Tabel 3. Rumusan Indikator Pencapaian Kompetensi Lingkaran Kelas VIII SMP

\begin{tabular}{|c|c|c|c|c|c|}
\hline \multicolumn{2}{|r|}{ KD } & \multicolumn{2}{|r|}{ Indikator pada Silabus } & \multicolumn{2}{|r|}{ Indikator Susunan Baru } \\
\hline 4.1 & $\begin{array}{l}\text { Menentu } \\
\text { kan unsur } \\
\text { dan } \\
\text { bagian- } \\
\text { bagian } \\
\text { lingkaran. }\end{array}$ & 4.1 .1 & $\begin{array}{l}\text { Menyebutkan unsur- } \\
\text { unsur dan bagian-bagian } \\
\text { lingkaran: pusat } \\
\text { lingkaran, jari-jari, } \\
\text { diameter, busur, } \\
\text { talibusur, juring, } \\
\text { tembereng. }\end{array}$ & 1.1 .2 & $\begin{array}{l}\text { Mendefinisikan unsur-unsur dan bagian- } \\
\text { bagian lingkaran: pusat lingkaran, jari-jari, } \\
\text { diameter, busur, talibusur, juring, } \\
\text { tembereng dan apotema berdasarkan ciri- } \\
\text { cirinya. } \\
\text { Menunjukkan unsur-unsur dan bagian- } \\
\text { bagian lingkaran pada model atau gambar } \\
\text { lingkaran. }\end{array}$ \\
\hline 4.2 & $\begin{array}{l}\text { Menghi- } \\
\text { tung } \\
\text { keliling } \\
\text { dan luas } \\
\text { lingkaran. }\end{array}$ & $\begin{array}{l}4.2 .1 \\
4.2 .2\end{array}$ & $\begin{array}{l}\text { Menemukan nilai phi. } \\
\text { Menentukan rumus } \\
\text { keliling dan luas } \\
\text { lingkaran. } \\
\text { Menghitung keliling dan } \\
\text { luas lingkaran. }\end{array}$ & $\begin{array}{l}4.2 .1 \\
4.2 .2\end{array}$ & $\begin{array}{l}\text { Menemukan pendekatan nilai phi. } \\
\text { Menemukan rumus keliling dan } \\
\text { menggunakannya dalam menyelesaikan } \\
\text { masalah sederhana. } \\
\text { Menemukan rumus luas lingkaran dan } \\
\text { menggunakannya dalam menyelesaikan } \\
\text { masalah sederhana. }\end{array}$ \\
\hline 4.3 & $\begin{array}{l}\text { Menggu- } \\
\text { nakan } \\
\text { hubungan } \\
\text { sudut } \\
\text { pusat, } \\
\text { panjang } \\
\text { busur, dan } \\
\text { luas juring } \\
\text { dalam } \\
\text { pemeca- } \\
\text { han } \\
\text { masalah. }\end{array}$ & 4.3 .1 & $\begin{array}{l}\text { Menjelaskan hubungan } \\
\text { sudut pusat dan sudut } \\
\text { keliling jika menghadap } \\
\text { busur yang sama. } \\
\text { Menentukan besar sudut } \\
\text { keliling jika menghadap } \\
\text { diameter dan busur } \\
\text { yang sama. } \\
\text { Menentukan panjang } \\
\text { busur, luas juring, dan } \\
\text { luas tembereng. } \\
\text { Menggunakan } \\
\text { hubungan sudut pusat, } \\
\text { panjang busur, luas } \\
\text { juring dalam pemecahan } \\
\text { masalah. }\end{array}$ & 4.3 .1 & $\begin{array}{l}\text { Menjelaskan hubungan sudut pusat dan } \\
\text { sudut keliling jika menghadap busur yang } \\
\text { sama. } \\
\text { Menentukan besar sudut keliling jika } \\
\text { menghadap diameter dan busur yang } \\
\text { sama. } \\
\text { Menemukan hubungan sudut pusat dan } \\
\text { panjang busur dan menggunakannya } \\
\text { dalam pemecahan masalah. } \\
\text { Menemukan hubungan sudut pusat dan } \\
\text { luas juring dan menggunakannya dalam } \\
\text { pemecahan masalah. }\end{array}$ \\
\hline
\end{tabular}


Perumusan ulang indikator pencapaian kompetensi didasarkan pada beberapa pertimbangan. Pertama, kompetensi dasar 4.1 tidak cukup diukur dengan satu indikator saja sehingga dijabarkan menjadi dua indikator. Kedua, indikator 4.2.2 dan 4.2.3 disusun ulang dengan memisahkan indikator tentang keliling dan luas lingkaran. Hal ini dimaksudkan agar pembelajaran terfokus pada keliling lingkaran saja atau luas lingkaran saja. Dan ketiga, indikator 4.3.3 dan 4.3.4 juga disusun ulang agar pembelajaran terfokus pada panjang busur saja atau luas juring saja.

\section{Hasil Analisis Konsep}

Analisis konsep bertujuan untuk menentukan materi-materi yang dibutuhkan dalam pengembangan perangkat pembelajaran untuk mencapai indikator-indikator pencapaian kompetensi. Untuk mencapai indikator 4.1.1 dan 4.1.2 diperlukan materi tentang unsur-unsur dan bagian-bagian lingkaran yang meliputi pusat lingkaran, jari-jari, diameter, busur, talibusur, juring, tembereng dan apotema. Untuk mencapai indikator 4.2.1, 4.2.2, dan 4.2.3 dibu-tuhkan materi tentang keliling lingkaran dan luas ling-karan. Sedangkan untuk mencapai indikator 4.3.1, 4.3.2, 4.2.3, dan 4.2.4 membutuhkan materi tentang hubungan sudut pusat dan sudut keliling yang menghadap busur yang sama, sifat sudut keliling yang menghadap diameter dan busur yang sama, panjang busur, dan luas juring.

Materi atau konsep-konsep yang dibutuhkan dalam pembelajaran kemudian disusun dalam bentuk peta konsep yang menggambarkan keterkaitan antar materi dan urutan logis penyajian materi berdasarkan materi yang saling memprasyarati jika ada. Peta konsep materi lingkaran dapat dilihat pada Gambar 3.

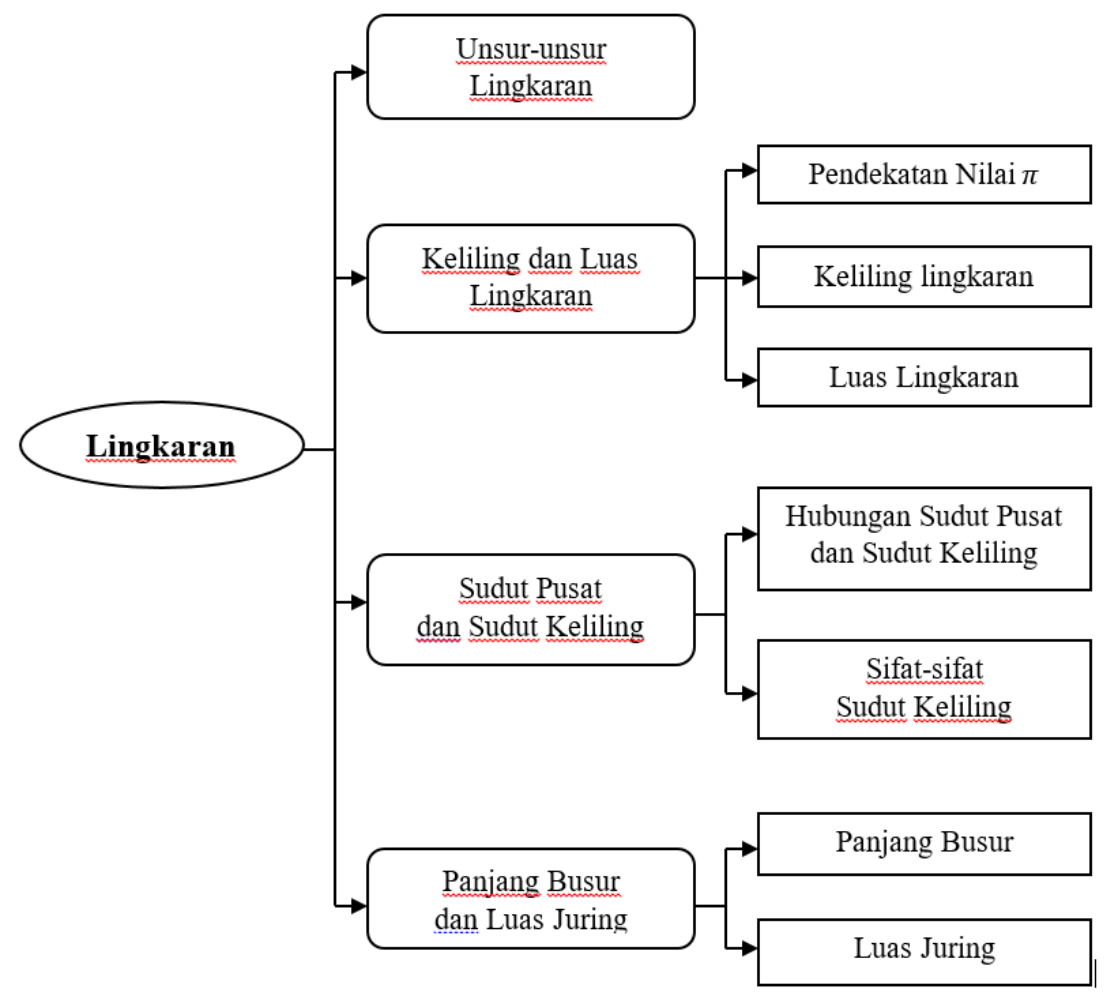

Gambar 3. Peta Konsep Materi Lingkaran 


\section{Hasil Analisis Bahan Ajar yang Ada}

Bahan ajar yang digunakan masih terbatas baik dalam segi kuantitas maupun kualitas. Tidak semua siswa memiliki buku paket dan buku paket sehingga penggunaannya masih belum optimal dalam membantu pelaksanaan pembelajaran. Bahan ajar yang digunakan hanya memuat ringkasan materi dan kumpulan soal sehingga masih membutuhkan banyak penjelasan dari guru. Tidak adanya petunjuk tertulis pada bahan ajar tentang langkah-langkah kegiatan yeng harus dilakukan oleh siswa juga menyebabkan bahan ajar belum bisa digunakan secara mandiri oleh siswa baik secara individu maupun berkelompok.

Berdasarkan kekurangan bahan ajar yang telah digunakan, diperlukan bahan ajar yang memuat langkah kegiatan penemuan yang jelas sehingga dapat membantu guru dan siswa dalam melaksanakan pembelajaran secara lebih terarah. Pada kegiatan pendahuluan diberikan pemberian masalah yang berhubungan dengan materi yang akan dipelajari sebagai rangsangan pada siswa untuk berpartisipasi aktif dalam proses pembelajaran. Selain itu pada kegiatan pendahuluan juga disampaikan tujuan pembelajaran dan cara belajar agar siswa lebih terarah pada apa yang harus dicapai dan dilakukan selama proses pembelajaran (Hidayat, Mulyati \& Qohar, 2017).

Pada kegiatan inti, siswa dibimbing, diarahkan dan difasilitasi untuk memahami langkah kerja, ilustrasi atau penjelasan yang diberikan pada lembar kerja kemudian menjawab, pertanyaan atau perintah yang mengikutinya. Pembelajaran diakhiri dengan kegiatan membuat rangkuman atau kesimpulan tentang materi yang telah dipelajari dan telah didiskusikan secara klasikal, mengerjakan soal-soal latihan, dan guru informasikan materi yang akan diperlajari pada pertemuan berikutnya .

\section{Simpulan}

Berdasarkan hasil analisis kebutuhan, peneliti merekomendasikan pengembangan bahan ajar berbasis penemuan terbimbing dalam bentuk lembar kerja siswa. Hal ini bertujuan untuk mempermudah guru dalam membimbing siswa dalam melakukan kegiatan penemuan. Kegiatan pembelajaran pada lembar kerja disesuaikan dengan langkah-langkah pembelajaran penemuan terbimbing yang meliputi kegiatan pemberian ransangan (stimulation), perumusan masalah (problem statement), pengumpulan data (data collection), pengolahan data (processing data), pengujian hipotesis (verification), dan penarikan kesimpulan (generalization) (Hidayat, Mulyati \& Qohar, 2017).

Karakteristik lembar kerja siswa yang perlu dikembangkan diharapkan memenuhi kriteria pada beberapa aspek berikut.

a. Aspek Didaktik

Pembelajaran diawali dengan memberikan permasalahan dalam kehidupan sehari-hari yang berkaitan dengan materi yang dipelajari dengan tujuan menggugah siswa untuk melakukan kegiatan penemuan. Untuk lebih menarik perhatian siswa, pada permasalahan juga diberikan gambar yang relevan dengan masalah yang disajikan. Selain itu, materi tidak disajikan dalam bentuk jadi tetapi ditemukan melalui kegiatan penemuan. Pada bagian akhir kegiatan penemuan selalu diikuti dengan beberapa pertanyaan-pertanyaan pemandu yang mengarahkan siswa untuk membuat kesimpulan dari kegiatan penemuan yang telah dilakukan secara berkelompok. 
b. Aspek Isi

Materi dan kegiatan penemuan yang disajikan sesuai dengan indikator pencapaian kompetensi. Misalnya, untuk mencapai “indikator menemukan pendekatan nilai $\pi$ ” siswa dihadapkan pada kegiatan pengukuran keliling dan diameter benda-benda berbentuk lingkaran dengan tujuan menemukan pendekatan nilai $\pi$ dari hasil bagi keliling terhadap diameter benda berbentuk lingkaran. Kegiatan penemuan dilengkapi dengan keterangan tentang alat-alat yang dibutuhkan dan cara kerja yang jelas disertai gambar agar proses pembelajaran berjalan dengan menarik dan menyenangkan.

c. Aspek Bahasa

Penulisan dan bahasa yang digunakan pada lembar kerja sesuai dengan ejaan yang disempurnakan (EYD). Lembar kerja menggunakan bahasa yang sederhana dan komunikatif serta sesuai dengan tingkat pemahaman siswa SMP dan menghindari penggunaan istilahistilah yang sulit dipahami oleh siswa. Selain itu, perintah dan pertanyaan-pertanyaan pada lembar kerja disusun dengan kalimat yang jelas sehingga mampu mengarahkan siswa melakukan kegiatan atau menjawab pertanyaan sesuai dengan yang diharapkan.

\section{Daftar Rujukan}

Adawiah, Rabiatul. (2016). Pengembangan Lembar Kerja Siswa (LKS) Materi Pecahan Berbasis Metode Penemuan Terbimbing Untuk Kelas VII Siswa SMP. Jurnal Ilmiah Mahasiswa FKIP Prodi Matematika, 2(1).

Bani, Asmar. (2011). Meningkatkan Kemampuan Pemahaman dan Penalaran Matematik Siswa Sekolah Menengah Pertama Melalui Pembelajaran Penemuan Terbimbing. Bandung: Universitas Pendidikan Indonesia.

Herawaty, Dewi. (2017). Peningkatan Kompetensi Siswa SMP di Kota Bengkulu melalui Penerapan Model Pembelajaran Matematika (MPM-SMP). Jurnal Pendidikan Matematika Raflesia, 2(1).

Hidayat, Toni; Mulyati, Sri \& Qohar, Abd. (2017). Penerapan Metode Penemuan Terbimbing di Kelas VIII SMP. Jurnal Pendidikan: Teori, Penelitian, dan Pengembangan, 2(8), 1116-1122.

Indriani, Marisa; Niswah, Choirun \& Arifin, Sujinal. (2017). Pengembangan Lembar Kerja Peserta Didik (LKPD) Berbasis Inkuiri Terbimbing pada Materi Transformasi Geometri. Jurnal Pendidikan Matematika RAFA, 3(2), 165-180.

Kesumawati, Nila. (2008). Pemahaman Konsep Matematik dalam Pembelajaran Matematika. Semnas Matematika dan Pendidikan Matematika, 2, 231-234.

OECD. (2016). PISA 2015 Result. OECD (Organitation for Economic Co-operation and Development).

Pramudi, Titis Abimanyu; Yennita \& Primairyani, Ariefa. (2016). Pengembangan Lembar Kerja Siswa Berbasis Discovery pada Pembelajaran Struktur dan Fungsi Jaringan Tumbuhan. Journal of Biology Education, 5(3), 279-285. 
Selviana, Dita. (2016). Pengembangan LKS Berbasis Inkuiri Terbimbing pada Materi Struktur dan Fungsi Jaringan Tumbuhan di SMP. (Doctoral dissertation, Universitas Negeri Semarang).

Suherman, E. (2003). Strategi Pembelajaran Matematika Kontemporer. Bandung: JICA.

Surbakti, Ermelia. (2016). Pengembangan LKS Matematika Berbasis Penemuan Terbimbing Siswa Kelas VII SMP Materi Bangun Datar Segi Empat. Jurnal Mahasiswa Prodi Matematika UPP, 2(1).

Taqiyyah, Syir Anatut; Subali, Bambang \& Handayani, Langlang. (2017). Implementasi Bahan Ajar Sains Berbahasa Inggris Berbasis Metakognitif untuk Meningkatkan Kemampuan Pemecahan Masalah Siswa SMP. Jurnal Inovasi Pendidikan IPA, 3(2), 224-234.

Wahyuni, Rizki; Yunarti, Tina \& Noer, Sri Hastuti. (2017). Pengembangan LKPD Berbasis Penemuan Terbimbing untuk Memfasilitasi Kemampuan dan Disposisi Pemahaman Konsep Matematis. Jurnal Pendidikan Matematika Unila, 5(5).

Yanti, Yulia Damai, \& Arcat, Hardianto. (2017). Pengembangan Lembar Kerja Siswa (LKS) Matematika Berbasis Penemuan Terbimbing untuk Siswa Kelas VIII Sekolah Menengah Pertama pada Materi Kubus, Balok, Prisma Dan Limas. Jurnal Ilmiah Mahasiswa FKIP Prodi Matematika, 2(1).

Yudhi, Prima (2017). Analisis Kebutuhan Pengembangan Lembar Kerja Siswa Berbasis Realistics Mathematics Education (RME) PADA Materi FPB dan KPK untuk Siswa Kelas IV Sekolah Dasar. Menara Ilmu, 11(74), 144-149.

Yuliyanto \& Jailani. (2014). Pengembangan Perangkat Pembelajaran Geometri SMP Menggunakan Metode Penemuan Terbimbing pada Kelas VIII Semester II. Jurnal Riset Pendidikan Matematika, 1(1), 127-138.

Yusnia, Desy \& Suparman. (2018, Februari). Analisis Kebutuhan Bahan Ajar Berbasis Guided Discovery. Dipresentasikan pada Prosiding Seminar Nasional Pendidikan Matematika Etnomatnesia. 